\title{
Can Children's Books Help Children Embracing Death as a Part of Life? The Case of Tuck Everlasting (1975)
}

\section{Ölüimüin de Hayatın Bir Parçası Olduğunu Çoculkların Kabulllenmesi için Çocuk Kitaplarından Yararlanılabilir Mi? Ölümsüz Aile (1975) Örneği}

Halil TEKINER $^{\mathrm{a}}$

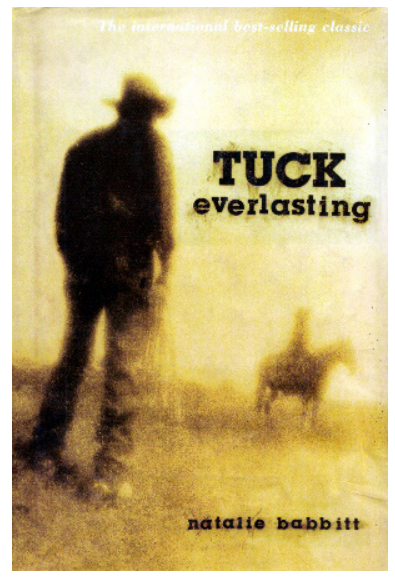

Natalie Babbitt

Tuck Everlasting

2002, 139 pages

Bloomsbury Publishing

Talking with children about death, dying, or bereavement is a sensitive and difficult situation that requires special concern. Parents' and caregivers' tendencies in these cases are sometimes to hide the truth, and hence children do not become truly informed until much later in life. From a bioethical perspective, however, children deserve respect and personal dignity, giving them the right to know the truth regardless of their age (1).

With patient autonomy now considered of paramount importance by medical professionals across the world, ultimate decision-making power belongs firmly in the hands of patients. Likewise recent ethical guidelines in pediatric care highlight respect for children's autonomy and respect for the truth. For instance, the Medical Ethics Manual of the World Medical Association states, "if a patient is a minor or otherwise legally incompetent, the consent of a legally entitled representative is required in some jurisdictions. Nevertheless the patient must be involved in the decision-making to the fullest extent allowed by his/her capacity" (2). The American Academy of Pediatrics is also in support for children bearing decisionmaking responsibility on matters pertaining to life-saving or life-sustaining medical treatment (3).

Yet, it is not easy to find the right tone when addressing a child's own world, perception, and imagination regarding death, dying, or bereavement. This is a thorny concept, but it should be addressed with the best interests of minor patients in mind and with their active participation regarding any decisions made that affect themselves in addition to their legal dependents.

${ }^{a}$ Assoc. Prof. Dr., Erciyes University Faculty of Pharmacy, Department of the History of Pharmacy and Ethics $₫$ htekiner@erciyes.edu.tr

Gönderim Tarihi: $08.01 .2020 \bullet$ Kabul Tarihi: 10.01.2020 
In parallel, it has been reported that with effect sizes ranging from small to moderate, bibliotherapy has positive outcomes with respect to children's behavioral problems; and carefully selected children's books may be useful in helping children embrace death as part of life (4). From Aesop's Fables to Anderson's tales, or Doris Buchanan Smith's A Taste of Blackberries (1973) to Patrick Ness's A Monster Calls (2011), numerous literary works give reference to death, dying, and bereavement (5).

One of the best examples in children's literature of modern times is found in the fantasy novel Tuck Everlasting (1975), written by the American author Natalie Babbitt (1932-2016), which has sold more than five million copies and was also adapted into two feature films and a musical.

This novel follows Winnie Foster, a 10-year-old girl living in Treegap, New Hampshire. Winnie has run away from home and discovered a profound secret when she encounters the Tuck family who gained a mysterious form of immortality after drinking water from a special spring. Despite their seeming gift, the Tucks live a quiet life, viewing their immortality as much as a curse as it is a blessing. Soon after Winnie finds them, the Tucks are also discovered by the man in the yellow suit, who has begun to track their movement and follow them. After hearing of their story as a boy, this man now pursues the Tucks and seeks to bottle their magical spring water to make his fortune. In making their escape, the Tucks and Winnie come face to face with the choices they have made, and Winnie herself must decide whether to drink the spring water and give up a normal life or live on in spite of her mortality (6).

Exploring themes of immortality, life, and death, Tuck Everlasting is very likely to aid children in conceptualizing the meaning of death. Considering the fact that the book has been translated into many major languages of the world, it is widely accessible for young school children as well.

Some related citations from the book are useful to exemplify its approach: "But dying's part of the wheel, right there next to being born. You can't pick out the pieces you like and leave the rest. Being part of the whole thing, that's the blessing (p.63). You can't have living without dying. So you can't call it living, what we got. We just are, we justbe, like rocks beside the road" (p.64). Some parts of the book also encourage accepting changes and difficulties in life while continuing to live: "Life's got to be lived, no matter how long or short," she said calmly. "You got to take what comes. We just go along, like everybody else, one day at a time" (p.54). "Life. Moving, growing, changing, never the same two minutes together. This water, you look out at it every morning, and it looks the same, but it ain't. All night long it's been moving...” (p.61) (6).

While post-reading assignments or group discussions about the book can be used to better understand the meaning of living and death, evidence-based scientific research with large sample sizes is required to demonstrate the real effectiveness of children's books to help children embracing death as a part of life. Such studies would allow us to confirm once and for all that children's literature can be used as a valuable tool to aid children in their embracing and understanding of death. 


\section{REFERENCES}

1. Hudson N, Spriggs M, Gillam L. Telling the truth to young children: ethical reasons for information disclosure in paediatrics. JPCH 2019; 55(1): 13-17.

2. Williams JR. Medical Ethics Manual: Manual for Physicians about the Role of Ethics in Medicine. $3^{\text {rd }}$ edition. Ferney-Voltaire: World Medical Association; 2015.

3. Cummings CL, Mercurio MR. "Session 2. Autonomy, beneficence, and the rights of parents and children: exploring the application of ethical principles in pediatrics," In: American Academy of Pediatrics Bioethics Residents Curriculum: Case-Based Teaching Guides. Diekema DS, Leuthner SR, Vizcarrondo FE, eds. Itasca, IL: American Academy of Pediatrics Committee on Bioethics and Section on Bioethics; 2017, p.12.

4. Berns CF. Bibliotherapy: using books to help bereaved children. Omega 2004; 48(4): 321-336.

5. Jones EH. Bibliotherapy for Bereaved Children: Healing Reading. London: Jessica Kingsley Publishers; 2001.

6. Babbitt N. Tuck Everlasting. London: Bloomsbury Publishing; 2002. 